\title{
ANAESTHESIA FOR DENTISTRY IN CHILDREN: A REVIEW OF 101 SURGICAL PROCEDURES
}

\author{
JoHN G. SCOTT, M.B., B.S., F.F.A.R.C.S., AND \\ David Allan, M.B., CH.B."
}

Dentistry For CHILDREN may present a variety of difficulties to the patients themselves and to the dentists, paedodontists, or oral surgeons who treat them. This is true of all paediatric patients, including those who are essentially healthy. Psychiatrists and dentists concerned with preventative practices, for example, have pointed out that extensive procedures may be emotionally as well as physically traumatic ${ }^{1}$ and that many children six years or younger should probably receive general anaesthesia if dentistry is likely to arouse pain or anxiety, if repeated or lengthy treatment sessions are required, and, in any case, for extractions.

When patients are children with coincidental disease, regardless of age, hospitalization and general anaesthesia are now increasingly regarded as desirable for dental conservation as well as for surgery. Today's consensus is that mentally retarded youngsters and those with cerebral palsy or other central nervous system disorders, abnormalities of the cardiovascular system, diabetes, congenital anomalies such as cleft lip and palate, or other serious problems are seldom, if ever, justifiably subjected to dentistry on an outpatient or ambulatory basis. From the standpoint of the dentist, paedodontist, or oral surgeon, patients who are not hospitalized or receive general anaesthesia require inordinate amounts of time for treatment; conditions may be unnecessarily trying for doctor and patient; risks may be incurred which could otherwise be eliminated. When facilities for hospitalization and the services of anaesthesiologists, especially specialists in paediatric anaesthesia, are available, minimal morbidity (and no mortality) will likely ensue regardless of the patient's general health or the extent of treatment.

The advent of the ultra-short acting barbiturates ${ }^{2}$ and non-barbiturate intravenous anaesthetic agents ${ }^{3}$ has also encouraged interest in general anaesthesia for procedures which might be carried out with more difficulty under local anaesthesia. "Continuous" injections of methohexitone 4 and thiopental sodium, and inductions by thiopental followed with inhalation anaesthesia are now being widely employed. Yet children, particularly those with coincidental disease, present special monitoring and airway management problems, and this tends to militate against prolonged dental treatment undertaken with general anaesthesia on patients who are not admitted to the hospital.

At Children's Memorial Hospital, Chicago, 97 children, from 2 to 15 years old, were studied over a four-year period as in-patients being treated extensively for

-Dr. Scott is Visiting Fellow, Department of Anesthesia, Northwestern University Medical School, Evanston, Illinois, and Clinical Fellow in Anesthesiology, Children's Memorial Hospital, Chicago. Dr. Allan is Head, Division of Anesthesiology, Children's Memorial Hospital, Chicago, and Associate Professor, Department of Anesthesia, Northwestern University Medical School, Evanston.

Canad. Anaesth. Soc. J., vol. 17, no. 4, July 1970 
dental problems in the course of 101 operations. This report reviews indications for general anaesthesia, the techniques employed, and the results in terms of operative and postoperative morbidity and complications. Figures 1 and 2 show patient ages, sex, and coincidental disorders.

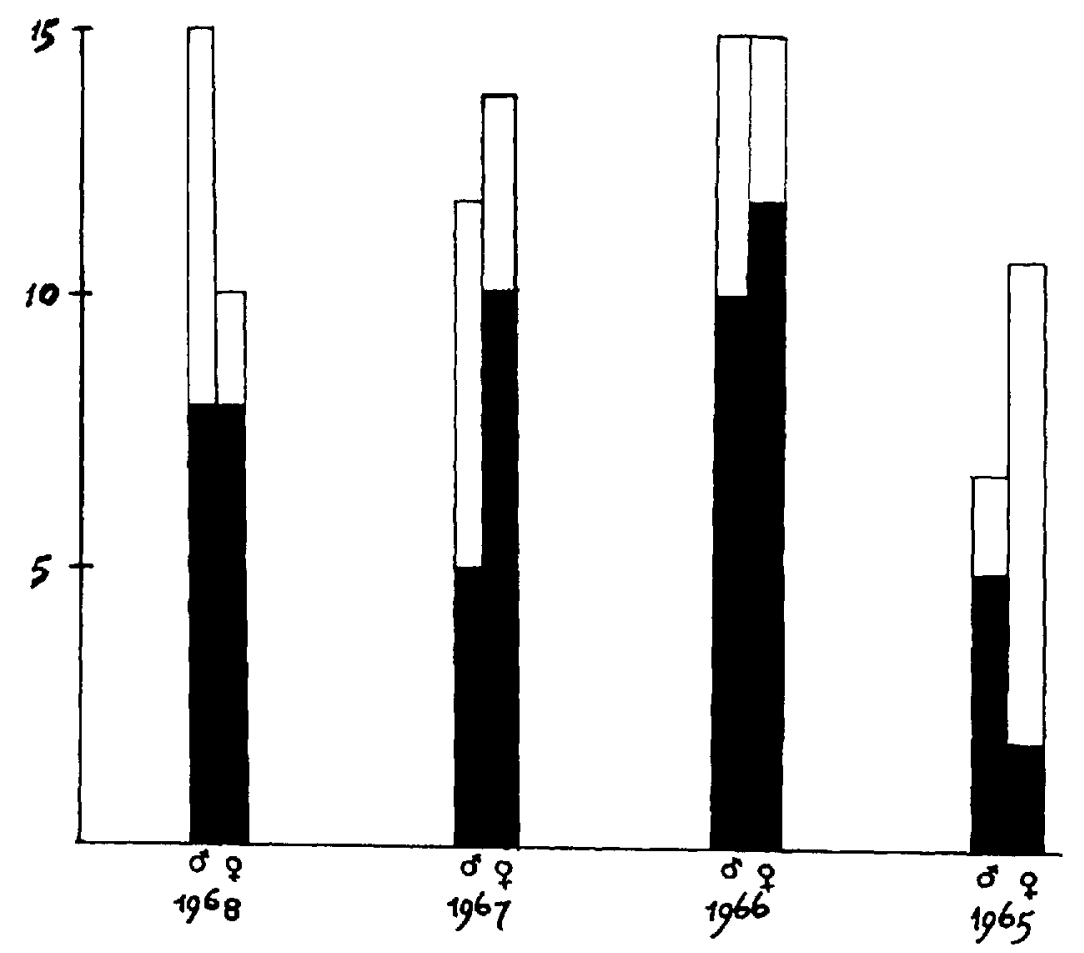

Frcure. 1. Number of patients per annum. The lower part of each column represents patients with coincidental disease.

\section{Method}

There were three underlying dental indications for the procedures (Table I). First, relating to the majority, was dental caries requiring extensive oral rehabilitation or extraction. Other indications, in order of frequency, included orthodontic treatments, trauma, and dental ankylosis, but these accounted for only seven of the 101 operations. Most procedures were prolonged, ranging from 30 minutes to 3.5 hours. Only three patients had simple extractions. All others underwent preparation and fillings of cavities in carious teeth, taking more than an hour in 88 cases. Yet, more dental conservation was achieved in this time than, as others have reported, can usually be accomplished during similar periods with a cooperative, conscious patient in a dental chair. ${ }^{5}$

Coincidental disease also often contributed to the decision to employ general anaesthesia for these children (Table II). Various types of mental retardation were commonest. Anaesthetizing such patients often provides the only opportunity for dental specialists to inspect and treat the mouth. Congenital cardiac or circulatory abnormalities also determined the use of general anaesthesia, largely be- 


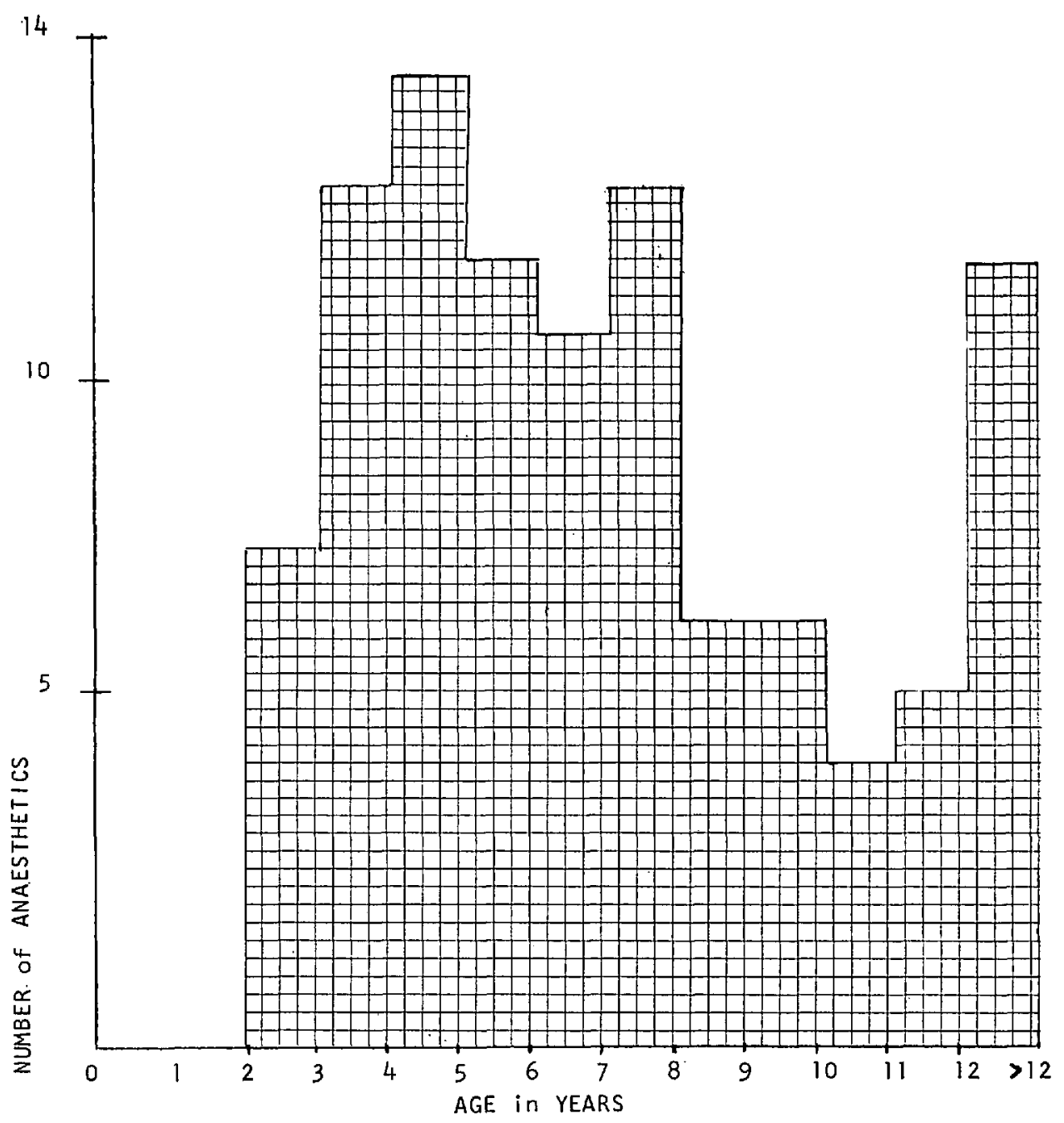

FIGURE 2. Age distribution of patients anaesthetized.

cause of the dangers of bacteraemia associated with dental manipulations and risk of consequent sub-acute bacterial endocaridits. ${ }^{6-8}$ Hospitalization is regarded as mandatory in such circumstances, not only for oral surgery when congenital heart lesions are present, but also for antibiotic therapy.

Children whose general condition would make them difficult to manage in the dental chair formed another category in which the decision was made for general anaesthesia. Included were those with neurological lesions, hydrocephaly, hemiplegia, and tetraplegic spasticity.

Ten patients with repaired cleft lips and/or cleft palates were also hospitalized and anaesthetized for treatment. These children, because of malocclusions, are especially liable to develop dental caries. Conservation of teeth requires particular care in such patients as prostheses depend upon them. ${ }^{9}$ 
TABLE I

Dental Indications for Surgical Procedures

\begin{tabular}{lc}
\hline \hline & Number of patients \\
\hline Trauma & 2 \\
Orthodontic procedures & 4 \\
Dental ankylosis & 1 \\
Caries & 94 \\
\hline
\end{tabular}

TABLE II

Coincidental Diseases

\begin{tabular}{lc}
\hline \hline & Number of patients \\
\hline Mental retardation & 12 \\
Congenital heart abnormalities, & 15 \\
$\quad$ of which had undergone some & \\
$\quad$ degree of surgical correction & \\
Downs' syndrome & 6 \\
cNs disease & 11 \\
$\quad$ (3 cNs tumours, 2 hydrocephalics, & \\
4 quadriplegics, 2 epileptics) & 10 \\
Cleft lip and palate & 2 \\
Laryngeal papillomas & 1 \\
Hypothyroidism & 1 \\
Idiopathic thrombocytopenic purpura & 1 \\
Diabetes mellitus & 1 \\
Rheumatic fever & 1 \\
Treacher Collins syndrome & 1 \\
Burn contractures affecting mouth & 1 \\
Fibrocystic disease (mucoviscidosis) & \\
\hline
\end{tabular}

Seven other types of coincidental disease were found in the study patients. Of these, three posed special anaesthetic or surgical problems: idiopathic thrombocytopenic purpura, Treacher Collins syndrome, and throat and neck scars and distortions, sequelae of burns from previous ingestion of caustic lye. Hypothyroidism, fibrocystic disease, diabetes mellitus, and extinct rheumatic fever were also found among the patients, but did not complicate anaesthetic management.

The anaesthesia technique varied little among the patients studied. Premedications, meperidine hydrochloride $(1-1.5 \mathrm{mg} / \mathrm{kg})$ and atropine sulphate $(0.01-0.02$ $\mathrm{mg} / \mathrm{kg}$ ), were injected intramuscularly 45 minutes to one hour before induction of anaesthesia. Several of the older patients expressed a preference for intravenous induction and were given 2.5 per cent thiopental $(5 \mathrm{mg} / \mathrm{kg})$. Children with congenital or acquired heart disease received procaine penicillin $(300,000-600,000$ units) intramuscularly at the same time as the premedication, and each six hours for 24 hours thereafter.

Anaesthesia was induced with nitrous oxide and oxygen (50:50 ratio) at a flow rate of $8 \mathrm{~L} / \mathrm{min}$. Halothane was added to 3 per cent, through a Fluotec vaporizer. With the establishment of smooth anaesthesia, the children were given intravenous injections of succinylcholine $(1 \mathrm{mg} / \mathrm{kg})$ to facilitate tracheal intubation, with the exception of three patients whose tracheostomies could be intubated directly. An endotracheal tube and pharyngeal pack was considered essential to maintain and protect the airway in all patients. ${ }^{10,11}$ On 67 of the 101 occasions, a 
Portex tube was passed through the nose and placed in the trachea with Magills forceps; in the other instances, a red rubber oro-endotracheal tube was passed. All intubations were made under direct vision. ${ }^{12}$

Two anaesthetic circuits were employed. For children weighing more than $20 \mathrm{~kg}$ a non-rebreathing circuit was chosen incorporating an ultrasonic nebulizer and a Sierra non-rebreathing valve (Fig. 3). Smaller children were anaesthetized

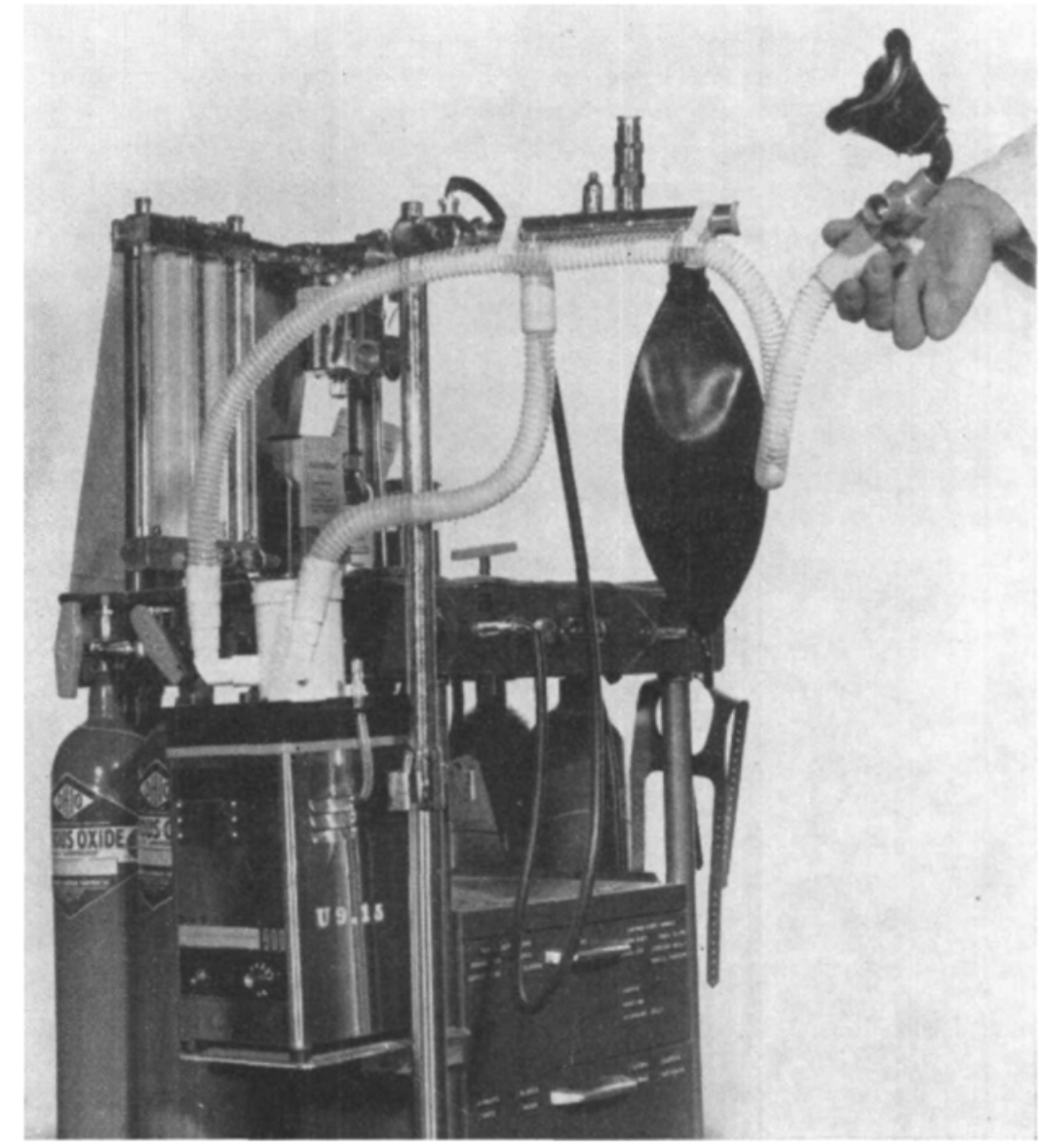

FIGURE 3. Humidified non-rebreathing circuit: DeVilbiss 900 ultrasonic nebulizer with Sierra valve.

with an adaptation of Jackson-Rees' modification of the Ayres' ${ }^{3}$-piece, ${ }^{13}$ with an ultrasonic nebulizer included in the circuit to particularize distilled water and provide humidification (Fig. 4). ${ }^{14}$

Anaesthesia in all patients was maintained with halothane (0.5-1.5 per cent) with $\mathrm{N}_{2} \mathrm{O}$ and $\mathrm{O}_{2}$ in equal $4 \mathrm{~L}$ volumes. Spontaneous or assisted respiration followed the resumption of muscular activity after the succinylcholine injections.

A precordial stethoscope, an electrocardioscope, and a blood pressure cuff were used to monitor the condition of each patient continuously. Temperatures were 


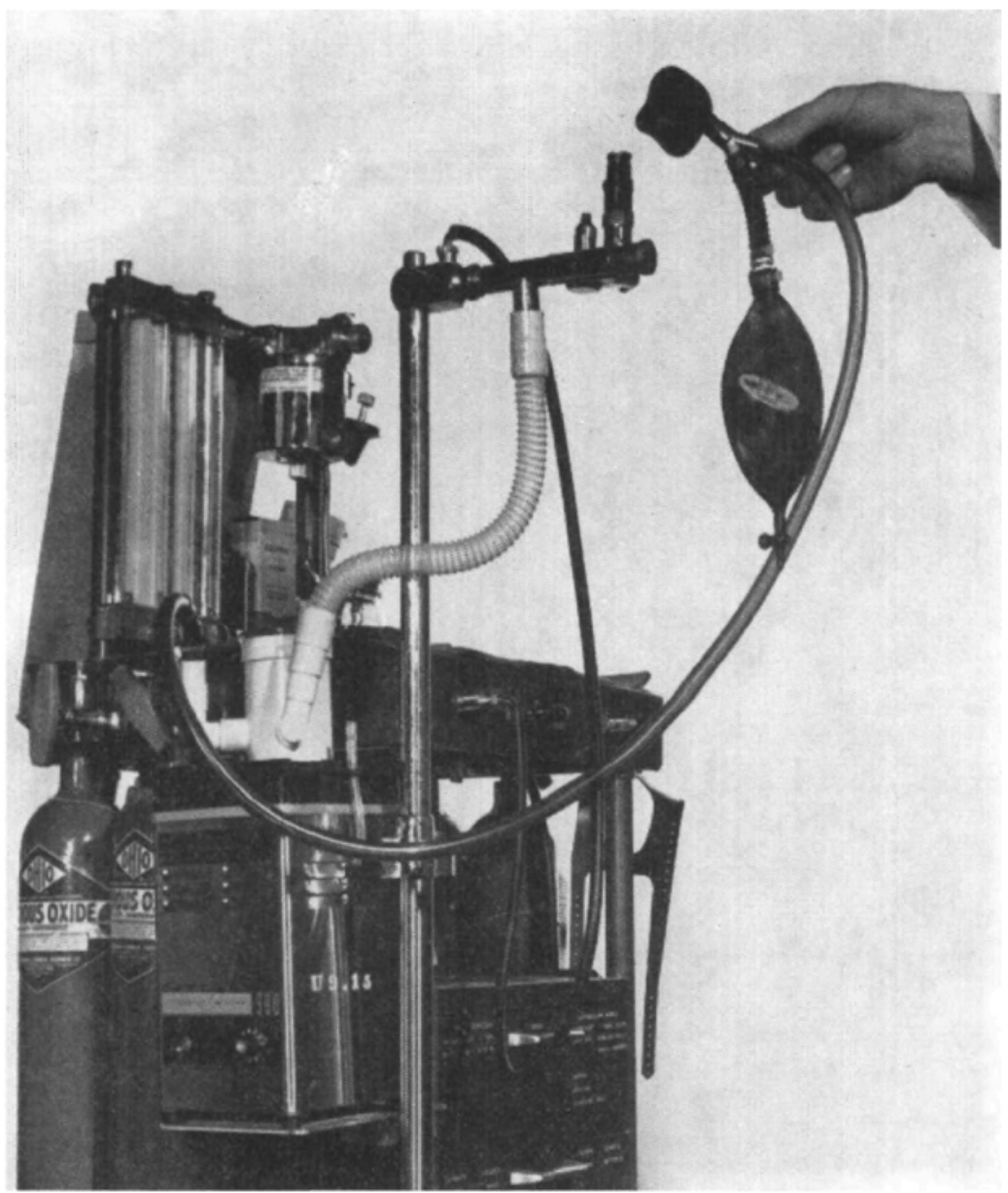

Figure 4. Humidified modified Ayres' T-piece circuit: DeVilbiss 900 ultrasonic nebulizer.

recorded with a rectal thermistor probe; data were introduced into the servomechanism of a cooling-heating pump which automatically controlled the temperature of the water mattress (between $60^{\circ}$ and $105^{\circ} \mathrm{F}$ ) on which patients lay.

At the end of the procedure, halothane and $\mathrm{N}_{2} \mathrm{O}$ were shut off and the throat pack removed. The anaesthesiologist then inspected the pharynx and throat. Any remaining secretions, blood, or debris were removed by suction. Patients were then turned onto one side, extubated, and returned to the recovery room.

\section{RESULTS}

Few complications were encountered during anaesthesia. In three instances, however, there was failure of nasal intubation.

One child, a six-year-old girl with Treacher Collins syndrome, had dystocia of the mandible and choanal atresia. On the two occasions during dental surgery, 
attempts were made to pass an endotracheal tube through the nose. Both times this was unsuccessful; an oral tube was employed instead.

A three-year-old female, otherwise normal, had a septal deviation which presented considerable technical difficulty to naso-tracheal intubation. This was eventually achieved however. On extubation of the trachea, epistaxis persisted for 30 minutes.

A six-year-old male with idiopathic thrombocytopenic purpura received a platelet transfusion from four units of blood prior to operation. ${ }^{15}$

Two children developed circulatory changes during anaesthesia:

A normal boy, 3\%2 years old, developed cardiac arrhythmia, apparently an example of the phenomenon believed to be due to the stimulus of dental extraction. During the pulling of three teeth, his pulse rate suddenly decreased from 160 to $120 /$ min. as traction was applied in each instance. Pulse returned to normal when extraction was complete.

On induction of anaesthesia, a girl of seven, who had earlier been successfully treated for transposition of the great vessels, developed idiopathic cardiac ventricular arrhythmia with a pulse rate of $44 / \mathrm{min}$. With intravenous injection of atropine $(0.2 \mathrm{mg}),{ }^{16}$ the pulse rate returned to $120 / \mathrm{min}$. Shortly after tracheal intubation, the ventricular irregularity was observed once more. Again, atropine $(0.2 \mathrm{mg})$ was given. The intravenous injection was followed by resumption of sinus rhythm and a pulse rate of $128 / \mathrm{min}$. Thereafter, anaesthesia, surgery, and recovery were uneventful.

Only 21 patients suffered postoperative complications. Sixteen of these had emesis, an incidence among 101 recoveries that may be considered unremarkable. One patient, however, had an unexpected reaction to a widely used antiemetic agent. This was a six-year-old female, weighing $16 \mathrm{~kg}$, with multiple congenital cardiovascular abnormalities including dextrocardia, hypoplastic left lung, and anomalous drainage of the lower lobe of the right lung into the inferior vena cava. She vomited and retched from the moment of recovering consciousness. In an attempt to relieve these symptoms, prochlorperazine (Compazine) was injected intramuscularly ( $10 \mathrm{mg}$ ). This was followed by trismus, hypertonicity, fever, and a strange, shrieking cry, which continued with diminishing intensity for $2 \%$ hours. Although we know of no similar cases, the bizarre behaviour on the heels of the injection of the antiemetic suggests idiosyncratic sensitivity to the agent.

Five patients had postoperative laryngospasm. These, and the child with mucoviscidosis, ${ }^{1}$ were treated in oxygen tents in atmosphere humidified by an ultrasonic nebulizer. ${ }^{17}$

\section{Discussion}

The demand for general anaesthesia for dental conservation has grown, from dentists and patients alike, during the last five years. Generally, this is based on a wish for the patient's increased comfort and improvement in operating conditions for the surgeon. Widespread popularity of "amnalgesia," 18 the Jorgenson technique, ${ }^{19}$ and "continuous" methohexitone ${ }^{4}$ in office practice has resulted.

Whenever anaesthesia is employed, however, paediatric patients provide special problems. Many of the children in the study series would have been inaccessible 
to the dental specialist working in his office. Further, many might have faced unwarranted hazards from "office" anaesthetic techniques.

Surgery, or other dental manipulations, require an anaesthesia with no risk of mortality and minimal morbidity. In children this presupposes perfect control of a small airway, continual, reliable monitoring of respiratory and cardiovascular status, and protection against compromises of normal physiological functioning due to the procedure or to the anaesthesia. The method of anaesthesia management described here is simple and, in the study series, resulted in an acceptably low incidence of complications. The inherent safety of the technique lay in the practice of admitting all the children to the hospital, where each patient was carefully evaluated before surgery and had the attention of staff specialists, and the benefits of sophisticated equipment. Although all our patients spent at least two nights in the hospital, we see no objection to admitting a healthy child on the day of operation and discharging him the same day, providing he has been previously evaluated with care, and all pertinent details of his history and status have been obtained (ASA, PSI). We feel that additional provision should be made to have the hospital stay of such a child prolonged should circumstances dictate it.

Our anaesthetic method is well adapted to meet and handle cardiovascular emergencies. The occurrence of cardiac irregularities during dental extractions is well known. ${ }^{20,21}$ Should severe arrhythmia, bradycardia, or arrest develop, the operating team is in the best possible position to remedy the situation. Continuous electrical monitoring should make recognition of such a situation instantaneous. Endotracheal intubation gives the anaesthesiologist complete control of the patient's airway. He also has access to the circulation through a previously inserted intravenous needle and an infusion. In emergency, therefore, the anaesthesiologist may depute inflation of the patient's lungs with oxygen to his surgical colleague. He may then give undivided attention to administering appropriate drugs, keeping close watch on their effects and any physiological changes, or if necessary, perform external cardiac massage.

In the study series, the dental surgeon first placed a pack in the oropharynx, then proceeded with dental restoration, leaving extractions until the end of the procedure. This reduced risk of debris becoming lodged in a socket. In some patients it was necessary to deepen anaesthesia just prior to extractions.

Recently, the use of a rubber dam has won increased acceptance among oral surgeons and other dental specialists. This device creates a dry surgical zone, and protects the mouth from debris dislodged while cavities are prepared. If extractions are not planned during a procedure, the rubber dam might theoretically make packing the oropharynx unnecessary. Extractions then would proceed after restoration work was finished as in patients with oropharyngeal packs. The effective use of rubber dams is enhanced by employing nasal (rather than oral) endotracheal tubes.

Surgery on dental patients in the hospital permits the extension of postoperative care for any appropriate period. While almost all patients will be ready for discharge on the same day, or on the morning after operation, those that may develop postoperative fever or respiratory or cardiovascular complications can be kept in the hospital. Those with haemorrhagic diseases, such as idiopathic thrombocyto- 
penic purpura or haemophilia, should remain in the hospital postoperatively for relatively extended periods as a precautionary measure. These patients are particularly liable to haemorrhage either in the time immediately following operation or between the fourth and sixth postoperative days. Those with haemorrhagic tendencies are best scheduled for surgery, therefore, on a Thursday or Friday, ${ }^{5}$ so a possible late episode will not coincide with the usual weekend reductions in laboratory and other personnel. Successful care of such patients results from close co-operation of surgeon, pathologist, and anaesthesiologist before, during, and after operation..$^{5}$

In paediatric centres such as ours, prolonged hospitalizations are frequently necessary to investigate major diseases. In such instances, dental operations can usually be arranged during a single admission without interfering with the rest of the child's clinical course. Some of our study patients, for example, underwent oral rehabilitation as a prelude to major cardiac surgery.

\section{SumMary}

Anaesthetic management was studied during 101 procedures for dental surgery or conservation in paediatric patients. Ninety-seven children from 2 to 15 years of age were investigated. Some were essentially healthy; others had coincidental diseases varying in severity. Since general anaesthesia for paediatric dentistry is gaining general acceptance, a simple technique with a low incidence of complications is suggested as having wide applicability.

\section{RÉSUMÉ}

Au cours d'une période de quatre ans, nous avons étudié, à l'hôpital Children's Memorial à Chicago, les cas de 97 enfants, agés de 2 à 15 ans, qui ont été hospitalisés et traités de façon extensive pour des problèmes dentaires et qui ont subi 101 opérations. Ce rapport passe en revue d'abord les indications pour une anesthésie générale; ensuite, les techniques employées; puis les résultats obtenus en termes de morbidité et de complications opératoires et post-opératoires. Les Tableaux I et II font voir les données au sujet de l'âge, le sexe, les désordres concomitants.

Les indications opératoires, d'ordre dentaire, se résument à trois (Tableau I): d'abord, pour la majorité des cas, il s'agissait de caries dentaires requérant une réhabilitation buccale extensive ou une extraction; ensuite, parmi les indications, il y avait des traitements orthodontiques; traumatisme, ankylose dentaire; cela, par ordre de fréquence, ne comptait que pour sept des 101 opérations. La plupart des opérations étaient assez longues: de 30 minutes à trois heures et cinq minutes. Seulement trois enfants ont subi des extractions simples. Tous les autres ont subi des préparations et des remplissages de cavités de dents cariées requérant plus d'une heure dans 88 cas. Durant ce temps, nous avons réussi à conserver plus de dents, comme le rapportent d'autres auteurs, qu'on ne peut le faire habituellement durant le même temps dans une chaise de dentiste avec un malade conscient et tout à fait coopérateur. 
Chez tous les malades, le maintien de l'anesthésie s'est fait avec de l'halothane ( 0.5 à 1.5 pour cent) et du $\mathrm{N}_{2} \mathrm{O}$ et de l' $\mathrm{O}_{2}: 4 \mathrm{~L} / \mathrm{min}$ chacun. Après les injections de succinylcholine et le retour de l'activité musculaire, les malades gardaient une ventilation spontanée ou assistée.

Pour surveiller les signes vitaux, nous avions pour chacun des malades et de façon continuelle: un stéthoscope précordial, un cardioscope, un appareil à pression artérielle. Un thermomètre rectal permettait l'enregistrement de la température, les données étaient transmises au servo-mécanisme d'une pompe chauffante et refroidissante on maintenait le température de l'eau dans le matelas (entre $60^{\circ}$ et $105^{\circ} \mathrm{F}$ ) sur lequel reposait le malade.

A la fin de l'opération, l'halothane et le $\mathrm{N}_{2} \mathrm{O}$ étaient discontinués et on enlevait les tampons du fond de la gorge. L'anesthésiste faisait alors l'inspection du rhinopharynx et de la gorge; à l'aide d'un aspirateur, il enlevait toutes les sécrétions, le sang ou tous les débris qui pouvaient s'y trouver. Après cela, on tournait les malades sur le côté, on les extubait et on les envoyait à la salle de réveil.

On a fait l'induction de l'anesthésie avec du protoxyde d'azote et de l'oxygène (50:50) à un débit de $8 \mathrm{~L} / \mathrm{min}$. A l'aide d'un vaporisateur Fluotec, on ajoutait 3 pour cent d'halothane. Après une douce induction de l'anesthésie, nous avons donné de la succinylcholine $(1 \mathrm{mg} / \mathrm{kg}$ ) par voie endoveineuse pour faciliter l'intubation de la trachée à l'exception de trois malades porteurs d'une trachéostomie que nous avons intubé directement. Chez tous les malades, dans le but d'établir et de maintenir une protection adéquate des voies respiratoires, nous avons jugé essentiel de placer un tube dans la trachée et un pansement protecteur dans le pharynx. Au cours de 67 des 101 opérations, nous avons passé un tube portex par le nez et l'avons dirigé dans la trachée à l'aide d'une pince Magill; au cours des autres opérations, nous avons employé un tube oro-trachéal en caoutchouc rouge. Toutes les intubations ont été faites sous vision directe. ${ }^{12}$

Nous avons employé deux circuits différents. Chez les enfants dont le poids dépassait 20 kilos, nous avons choisi un circuit sans réinspiration avec un nébulizateur ultrasonique et une valve Sierra sans réinspiration (Fig. 1). Pour les plus petits, nous les avons anesthésiés avec une adaptation de la technique JacksonRees et une modification du tube en $\mathrm{T}$ Ayre, ${ }^{13}$ incluant dans le circuit un nébulizateur pour procurer l'humidité désirée avec des particules d'eau distillée (Fig. 2). ${ }^{14}$

Souvent, ce fut la présence d'une maladie concomitante qui a joué un rôle dans la décision de recourir à l'anesthésie générale chez ces malades (Tableau II). Le plus souvent, il s'agissait de différents types d'arriérés mentaux. Des anomalies congénitales cardiaques ou circulatoires ont également fait opter pour l'anesthésie générale surtout à cause des dangers de bactériennes reliés aux manipulations dentaires et du risque d'endocardite bactérienne sub aigue subséquente. ${ }^{6-8}$ Chez ces malades, l'hospitalisation est une nécessité, non seulement en vue de la chirurgie buccale chez des porteurs de lésions cardiaques congénitales, mais aussi dans le but de pratiquer une thérapie aux antibiotiques.

Une autre indication de l'anesthésie générale était posée par ceux qu'il était impossible de traiter dans une chaise de dentiste à cause de leur état général. Parmi ceux-là, nommons les porteurs de lésions neurologiques: hydrocéphalie, hémiplégie, tetraplégie spastique. 
Des malades porteurs de "gueules de loup" ou de "becs de lièvre" réparés ont également été hospitalisés et anesthésiés pour traitements. Ces malades sont prédisposés aux caries dentaires à cause de malocclusions. Chez de tels malades, la conservation des dents requiert des soins particuliers, car c'est sur ces dents que les prothèses s'appuieront. ${ }^{\text {' }}$

Au cours de l'étude de ces malades, nous avons rencontré sept autres types de maladies concomitantes. Parmi celles-ci, trois d'entre elles posent des problèmes spéciaux soit en chirurgie, soit en anesthésie; un purpura thrombocytopenique idiopathique, un syndrome Collins Treacher, des cicatrices ou des malformations du cou ou de la gorge, séquelles de brûlures à la suite d'absorption antérieure de substances caustiques.

Chez ces malades, nous avons également observé des cas d'hypothyroidisme, de maladie fibrocystique, de diabète, d'ancienne fièvre rhumatismale; cependant, tout cela n'a pas créé de problèmes pour la conduite de l'anesthésie.

Parmi tous les malades que nous avons étudiés, la technique d'anesthésie n'a varié que très peu.

La prémédication a consisté en l'injection intramusculaire de chlorhydrate de mépéridine ( 1 à $1.5 \mathrm{mg} / \mathrm{kg}$ ) et de sulfate d'atropine $(0.01 \mathrm{à} 0.02 \mathrm{mg} / \mathrm{kg}$ ) 45 minutes à une heure avant l'induction de l'anesthésie. Parmi les plus agés, un bon nombre ont exprimé une préférence pour une induction par voie endoveineuse et nous l'avons pratiquée en donnant du thiopental à 2.5 pour cent $(5 \mathrm{mg} / \mathrm{kg})$. Les porteurs de maladies cardiaques congénitales ou acquises ont reçu, par voie intramusculaire, 300000 à 600000 unités de pénicilline procaine en même temps que la prémédication et, ensuite, à toutes les six heures durant les 24 heures suivantes.

\section{REFERENCES}

1. Weckstein, M. S. Basic Psychology and Dental Practice. In L. N. Hollander, Modern Dental Practice: Concepts and Procedures. Philadelphia: W. B. Saunders (1967), p. 49.

2. TAYlor, C. \& Steolting, V. K. Methohexital Sodium: A New Ultrashort Acting Barbiturate. Anesthesiology. 21: 29 (1960).

3. Howells, T. H.; Odell, J. R.; Hawkins, T. J.; \& Steane, P. A. An Introduction to FBS-1420, a New Non-barbiturate Intravenous Anaesthetic. Brit. J. Anaesth. 36: 295 (1964).

4. Cadle, D. R.; Boulton, T. B.; \& Spencer, S. M. Intermittent Intravenous Anaesthesia for Outpatient Dentistry. Anaesthesia. 23: 65 (1968).

5. Davies, R. M. \& Scort, J. B, Anaesthesia for Major Oral and Maxillofacial Surgery. Brit. J. Anaesth. 40: 202 (1968).

6. Blumenthal, S.; Guffrths, S. P.; \& Morgan, B. C. Bacterial Endocarditis in Children with Heart Disease. Pediatrics. 26: 993 (1960).

7. Rammedkamp, C. H., JR. Hemolytic Streptococcal Infections. In T. R. Harrison, Principles of Internal Medicine. 4th ed., New York: McGraw-Hill (1962), p. 901.

8. Fins, S. B. \& McCormick, J. Oral Cavity. In H. C. Shirkey, Pediatric Therapy. St. Louis: C. V. Mosby (1964), p. 463.

9. Sagarminaria, J. \& Wynamos, J. E. Atropine and the Electrical Activity of the Heart during Induction of Anaesthesia in Children. Canad. Anaesth. Soc. J., 10: 328 (1963).

10. Fry, I. K. \& EARL, C. J. Report on Inhalation of Blood and Debris during Dental Extraction. Guys Hospital Report. 99: 41 (1950).

11. Mapleson, W. W. The Elimination of Rebreathing in Semi-closed Anaesthesia Systems. Brit. J. Anaesth. 26: 323 (1954).

12. Annotation. Cardiac Irregularities during Dental Anaesthesia. Lancet. i: 754 (1966).

13. Love, S. H. The Complications of Dental Anaesthesia. Brit. J. Anaesth. 40: 188 (1968).

14. Allan, D. Personal communication. 
15. KaUfMaN, L. Cardiac Irregularities in Dentistry. Lancet. $i i: 287$ (1965).

16. Scotr, G. W. Inhalation and Chest Infection Following Dental Extractions. Guys Hospital Report. 107: 77 (1952).

17. Matthews, L. W. Application of Ultrasonic Nebulizer in the Treatment of Cystic Fibrosis. Proceedings of the First Conference on Clinical Applications of the Ultrasonic Nebulizer. Chicago: DeVilbiss (1966), p. 43.

18. Herzog, P.; Norlander, O. P.; \& Engstrom, C. G. Ultrasonic Generation of Aerosol for the Humidification of Inspired Gas during Volume-Controlled Ventilation. Acta Anesth. Scandinav. 8: 79 (1964).

19. Allan, D. A New Approach to Ultrasonic Mist Therapy in Children. J. Asthma Res. 5: 241 (1968).

20. Tom, A. Inhalational Analgesia in Dentistry. Brit. J. Anaesth. 40: 177 (1968).

21. Jorgensen, N. B. \& Leffingwel, F. Premedication in Dentistry. Dental Clin. N. Am. July, 299 ( 1966 ). 